\title{
Televizyon Haber ve Tartışma Programlarının Dili: Yeniden Söyleyiciliğe Yönelik Bazı Gözlemler
}

\author{
Mine Güven \\ ORCID ID: 0000-0002-1675-4478 \\ Doğuş Üniversitesi, Fen-Edebiyat Fakültesi, Ingilizce Mütercim ve \\ Tercümanlık Bölümü \\ guvenmine@outlook.com.tr
}

(Gönderilme tarihi 6 Temmuz 2020; kabul edilme tarihi 11 Haziran 2021)

ÖZ: Türkiye'de henüz uygulanmayan yeniden söyleyicilik (YS) yönteminde, canlı yayında işitilen sözel içerik, kısmen kısaltılıp yoğunlaştırılarak yinelenir. Otomatik konuşma tanıma yoluyla elde edilen yazılı metin, bir altyazılama bileşeninde düzenlenerek yayına verilir. $\mathrm{Bu}$ çalışmada ileride TV haber/tartışma programlarında YS'ye başvurulduğu takdirde Türkçe konuşma dilinin hangi yönlerinin dikkate alınması gerekeceği konusunda gözlemler sunulmuş ve özgün içeriğin altyazıya dönüştürülmesi sırasında yararlanılabilecek olası kısaltma/yoğunlaştırma stratejilerine değinilmiştir. Haber bülteni, ekonomi ve tartışma program kesitlerinden oluşturulan bir derlem (toplam 76 dakika 6 saniyelik ses/görüntü kaydı ve çevriyazı) nitel yöntemle çözümlenmiştir. Konuşma dilinin metin düzenleme işlemini etkileyebilecek yönleri arasında, sözdizim düzeyinde tümce uzunluğu, sözcük dizilişi ve anlatım bozukluklarının, anlambilim/edimbilim düzeyinde kip, kiplik ve sözeylem ifadelerinin, söylem düzeyinde ise bilgi içeriği düşük ögelerin (örn. dolgu sözcükleri, artıklık gösteren söylem belirleyicileri) bulunduğu saptanmıştır. Veriler, kısaltma/yoğunlaştırma stratejilerinden atlama ve yeniden biçimlendirme açısından da değerlendirilmiş olup gecikmeyi önlemek bakımından atlamaya öncelik verilebileceği gözlemlenmiştir.

Anahtar sözcükler: Canlı altyazılama, yeniden söyleyicilik, otomatik konuşma tanıma, atlama, yeniden biçimlendirme

\section{The Language of Television News and Debates: Some Observations Oriented Towards Respeaking}

ABSTRACT: Respeaking is a live subtitling method not yet practised in Turkey. A respeaker dictates the verbal content of a live TV program in reduced form to an automatic speech recognition engine which renders a written text to be post-edited on a subtitling component. This study presents a 
number of observations on those aspects of spoken Turkish which may be relevant to prospective respeaking practices for TV news and debates as well as on possible strategies to be employed while transforming the original content into subtitles. A qualitative analysis of a transcribed audiovisual corpus (total duration $76 \mathrm{~min} .6 \mathrm{sec}$.) comprising clips from news/economics programs and debates has shown that the following factors might influence text reduction during respeaking: sentence length, word order and ungrammaticality/disfluency on syntactic level; mood, modality and speech act expressions on semantic/pragmatic level and elements with low information content (e.g. fillers, redundantly used discourse markers) on discursive level. An evaluation of the data with respect to two text reduction strategies, namely omission and reformulation, has suggested that omission may be prioritized in order to prevent latency.

Keywords: Live subtitling, respeaking, automatic speech recognition, omission, reformulation

\section{Giriş}

Canlı altyazı (CA), işitme engeli olan ya da ileri yaşlarda işitme yitimiyle karşılaşan bireylerin görsel-işitsel (Gi) ürün ve hizmetlere erişimini kolaylaştıran bir altyazı uygulaması olup teknolojik altyapıya ve maddi olanaklara bağlı olarak stenografi, hızlı klavye veya yeniden söyleyicilik (YS) yöntemlerinden biriyle gerçekleştirilmektedir. Önceden hazırlanıp eşlenmiş altyazıların kullanılamadığı gerçek zamanlı televizyon (TV) programları için (örn. haber bültenleri ve tartışma programları) başvurulan CA, Türkiye'de henüz uygulanmamaktadır.

Radyo ve Televizyon Üst Kurulu (RTÜK) tarafindan düzenlenen bir çalıştayda, CA'nın "ana haber bültenleri” ve "olağanüstü veya acil durum haberlerinde" gerçekleştirilebilmesi için (i) "teknolojik gelişmelerin takip, teşvik ve temin edilmesi", (ii) konuyla ilgili araştırma yapılması ve (iii) sürdürülebilir hizmet için gereken "insan gücü ve teknoloji" altyapısının oluşturulması beklentisi dile getirilmiştir (RTÜK, 2019, s. 48). Avrupa ülkelerinde, TV ortamındaki ilk CA denemeleri 1980'li yıllarda gerçekleştirilmiş olsa da CA uygulamaları 2000'li yıllarda yaygınlaşmış olup özellikle YS konusundaki araştırmalar ağırlık kazanmıştır (Romero-Fresco, Melchor-Couto, Dawson, Moores ve Pedregosa, 2019, s. 218-219). Türkiye'deyse konferans ortamlarında hızlı klavye yöntemiyle CA uygulanmakta olsa da CA'yı konu alan herhangi bir bilimsel çalışma henüz yayımlanmamıştır. $\mathrm{Bu}$ bakımdan, YS'ye odaklanan bu çalışma, CA konusundaki araştırma boşluğunun giderilmesi yolunda bir adım olarak değerlendirilebilir. 
Sözü geçen bildirideki CA tanımında yer alan "işitselin/düzgünün ... yeniden düzenlenmesi" ve "bir çevirmen tarafından yeniden seslendirilmesi" ifadelerine bakılırsa (RTÜK, 2019, s. 42), öngörülen yöntem, stenografi ve hızlı klavye yöntemlerinde yeniden düzenleme ve seslendirme söz konusu olmadığından YS olmalıdır. Bu yöntemde, (tercihen çeviri eğitimi almış) bir görevli, yayında işitilen sözel içeriği mikrofon karşısında kısmen düzenlenmiş biçimde yineler. $\mathrm{Bu}$ ses girdisi (konuşmacıya bağımlı) bir otomatik konuşma tanıma (OKT) yazılımı yoluyla metne dönüştürülür. Bu metin de bir altyazı yazılımında düzenlenerek yayına hazır hale getirilir. $\mathrm{Bu}$ aşamada, yanlış tanınan sözcükler ya da noktalama işaretleri gözden geçirilebilir; içerik satırlara bölünebilir, vb. (Lambourne, 2006; Romero-Fresco, 2016, s. 57). ${ }^{1}$

$\mathrm{Bu}$ çalışmanın amacı, TV haber ve tartışma programlarında YS'ye başvurulduğu takdirde konuşma dilinin sözdizim, anlambilim/edimbilim ve söylem düzeylerindeki hangi yönlerinin dikkate alınması gerekeceği konusunda gözlemler sunmak ve özgün sözel içeriğin altyazıya dönüştürülmesi sırasında yararlanılabilecek olası kısaltma/yoğunlaştırma stratejilerine değinmektir. Bu amaçla, çeşitli TV kanallarında yayınlanmış haber bülteni, ekonomi ve tartışma programı kesitlerinden küçük bir derlem oluşturularak derlemin içerdiği dilsel yapılar nitel yöntemle ayrıntılı bir biçimde çözümlenmiştir. Aşağıdaki bölümlerde sırasıyla (i) çalışmanın çerçevesini oluşturan araştırma bulgularına değinilecek, (ii) derlem ve yöntemin tanıtılmasının ardından ayrıntılı bir veri çözümlemesi sunularak YS bağlamında karşılaşılacak olası sorun ve çözümler tartışılacak ve (iii) bulgular özetlenerek ilerideki çalışmalarda ele alınmaya değer noktalara dikkat çekilecektir.

\section{Yeniden Söyleyicilik ve Kısaltma/Yoğunlaştırma Stratejileri}

Banttan yayınlanan TV programlarından farklı olarak, önceden altyazı hazırlama ve/veya eşleme olanağı bulunmayan törenler, spor karşılaşmaları, sohbet programları gibi gerçek zamanlı yayınlar için başvurulan CA'nın olabildiğince az gecikmeyle (örn. Birleşik Krallık'ta 3 saniye) ama yüksek doğruluk oranıyla (örn. İspanya'da \%98) sunulması beklenmektedir (RomeroFresco, 2016, s. 68, 61). Ses, görüntü ve altyazının eşlenerek gecikmesiz biçimde sunulabilmesi içinse altyazı metninin konuşma hızında bilgisayara girilmesi gerekmektedir. CA için önceleri (en az \%95 doğruluk oranına

\footnotetext{
${ }^{1} \mathrm{Bu}$ yazıda kullanılan bazı terimlerin İngilizce karşılıkları şöyledir: başka biçimde ifade etme (paraphrasing), ilişkisel işlev taşıyan (phatic), işleyen bellek (working memory), kısaltma/yoğunlaştırma stratejisi (reduction/condensation strategy), ödünleme (concession), örtüşmeli konuşma (overlapping speech), sözcük hata oranı (word error rate), tutukluk/tereddüt (hesitation), yanıtsama (backchannel), yarım bırakılmış yapı (false start).
} 
ulaşılabilen) stenografi veya hızlı klavye yöntemleri denendiyse de (Lambourne, 2006, s. 2) günümüzde özellikle maliyet nedeniyle YS yeğlenmektedir. YS'de hem özgün metnin düzenlenmesi hem de OKT yoluyla çevriyazı üretimi sırasında gecikme meydana gelebilmektedir. Doğruluk oranıysa OKT başarımına bağlı olup henüz az sayıda doğal dil için yüksek başarıma ulaşan OKT geliştirilebilmiştir.

Arısoy, Can, Parlak, Sak ve Saraçlar (2009)'da sunulan verilere göre (büyük bölümü önceden hazırlanmış ve stüdyo koşullarında seslendirilmiş metinlere dayalı) Türkçe radyo/TV haber bültenlerinin çevriyazısına yönelik geliştirilmiş bir (konuşmacıdan bağımsız) OKT sisteminde, \%20 civarında olan sözcük hata oranı (s. 3, Tablo 3, s. 6, Tablo 5, s. 7), derin sinir ağları sayesinde $\% 10$ düzeyine indirilebilmiştir (Arısoy \& Saraçlar, 2018, s. 4, Tablo 1). OKT’den kaynaklanan gecikmenin azaltılması da sağlanmıştır (Saraçlar, Riley, Bocchieri ve Goffin, 2002).

TV programlarında bazen birden fazla kişi aynı anda ve hızlı bir biçimde konuşabilmekte ve işleyen belleği zorlayacak miktarda bilgi sunulabilmektedir. Bütün sözel içeriğin sözcüğü sözcüğüne aktarılması, hem ortalama izleyicinin okuma hızı ve bellek kapasitesini aşacak hem de ses-görüntü-altyazı eşlemesini bozacak kadar gecikmeli altyazılara neden olacağından YS'de kısaltma/yoğunlaştırmaya başvurulmaktadır (Luyckx, Delbeke, Van Waes, Leijten ve Remael, 2010, s. 5; Chmiel, Lijewska, Szarkowska ve Dutka, 2018, 726-727). Bunun yoluysa, gereksiz içeriği ayıklamak ve bilgi veren/anlamlı içeriği düzenleyerek başka biçimde ifade etmektir. Bir başka deyişle, önceden hazırlanan altyazılarda olduğu gibi YS'de de kısaltma/yoğunlaştırma amacıyla geliştirilmiş olan (i) atlama ve (ii) yeniden biçimlendirme stratejilerinden yararlanılmaktadır.

Önceden hazırlanan altyazılar söz konusu olduğunda, dile bağlı olarak değişmekle beraber, sözcük düzeyinde atlanabilecek ifadeler arasında (i) niteleyiciler (örn. sıfat, belirteç), (ii) ilişsisel işlev taşıyan (örn. biliyorsun) ya da kişilerarası ilişkilere yönelik ifadeler (örn. incelik, selamlaşma, hitap sözleri, ünlemler), (iii) yinelemeler, (iv) yarım bırakılmış yapılar ve tutukluk/tereddüt örnekleri bulunmaktadır. Öbek/tümce düzeyinde ise düşük bilgi içeren, kişisel görüş gösteren ya da konuşmacıların birbirlerinin sözlerini kendi sözcükleriyle yineledikleri ifadelerin çıkarılabileceği ileri sürülmüștür. Yine dile özgü olanaklar farklılık gösterse de içeriğin başka biçimde ifade edilmesi için şunlar önerilmiştir: (i) sıralamaların genelleştirilmesi, (ii) konu-odak ilişkisinin değiştirilmesi, (iii) çevrik eylem yapılarının, karmaşık tümce ve kiplik yapılarının sadeleştirilmesi, (iv) olumsuz ya da soru tümcelerinin olumlu düz tümcelere, edilgen yapının etken yapıya, dolaylı anlatımın dolaysız anlatıma dönüştürülmesi (Díaz Cintas \& Remael, 2007, s. 146-161; 162-171).

Belçika (Flaman) kamu kanalı VRT'deki bir deneyde, içeriğin sözcüğü sözcüğüne aktarılmasının beklendiği koşulda bile YS görevlileri sohbet 
programının hızına yetişebilmek için \%50'den fazla bir oranda kısaltma/yoğunlaştırmaya başvurmuş; ortalama gecikme süresi ise 12 saniye olmuştur (Luyckx ve diğerleri, 2010, Tablo 1, s. 15, s. 16). Başvurulan stratejiler arasındaysa (i) atlama (örn. yinelemeleri, yarım kalmış yapıları, izleyicilerin bağlamdan kestirebilecekleri düşünülen ayrıntıları, dolgu ve yanıtsama ifadelerini çıkarmak) ve (ii) yeniden biçimlendirme (örn. daha kısa, eşanlamlı sözcükler ya da eşdeğer ifadeler kullanmak; soru tümcelerini düz tümceye dönüştürmek ve kiplik ifadelerini sadeleştirmek) bulunmaktadır (Luyckx ve diğerleri, 2010, s. 23-27).

Türkçe TV haber ve tartışma programlarının dili, çeşitli açılardan ele alınmışsa da (örn. Yemenici, 1998; Yemenici, 1999; Ilgın, 2003) YS bağlamında konuşma diline ve kısaltma/yoğunlaştırma amacıyla başvurulan atlama ve yeniden biçimlendirme stratejilerine odaklanan herhangi bir çalışma bulunmamaktadır. Aşağıdaki bölümlerde önce derlem tanıtılacak, ardından da derlemin YS'de metin düzenleme işlemlerini etkileyebilecek yönleri irdelenecektir.

\section{Derlem ve Yöntem}

$\mathrm{Bu}$ çalıșmada çözümlenecek derlemin oluşturulması için 24 Temmuz-7 Ağustos 2019 tarihleri arasında rastgele kaydedilen yaklaşık 25 saatlik canlı haber bülteni ve/veya tartışma programı içinden kesitler alınmıştır. Bu kesitler, 17 farklı kanalda yayınlanmış olup 24 haber bülteni (HB) (toplam süre 2.430 sn. $(\% 53,22)$ ), 2 ekonomi konulu haber programı (HE) (toplam süre $159 \mathrm{sn}$. $(\% 3,48))$ ve (siyaset ya da başka bir güncel konu üzerinde) 12 tartışma/sohbet programı (TP) (toplam süre $1.977 \mathrm{sn}$. $(\% 43,3)$ ) olmak üzere üç kümede toplanmıştır (toplam 76 dakika 6 saniye). Derlemdeki kesitlerle ilgili bazı ayrıntılar Ek'te sunulmuş̧ur. Toplam 47 kadın ve 48 erkek sesinin işitildiği derlemin büyük bölümü, doğal konuşma verisinden oluşmaktadır (2.604/4.566 saniye $(\% 57,03))$. Haber bültenleri önceden yazılmış metinlere dayalı olsa da (HB1, HB6 ve HB12 dışındakilerde) doğal konuşmalar da işitilmektedir (uzman konuk, sokak görüşmeleri, görgü tanı̆̆ı) (1.962/4.566 saniye $(\% 42,97))$. Dış ses barındıran görüntü bantları dışındaki konuşmalar (örn. spiker, uzaktan bağlanan muhabir) canlı yayın sırasında anlık olarak gerçekleşmiştir. Çözümlenecek örneklerin seçiminde doğal konuşmalara öncelik verilmiş olup sadece (3), (55a) ve (62) bir metne dayalı olarak seslendirilmiştir. (63-64)'teki spiker ile (22) ve (10-55b)'deki muhabirlerse önceden tasarladıkları içeriği doğaçlama olarak sunmuşlardır. ${ }^{2}$

\footnotetext{
${ }^{2}$ Ek ve tablolardaki kısaltmalar şöyledir: haber bülteni (HB), haber bülteninde dış ses (HD), ekonomi haberi (HE), tartışma programı (TP), muhabir (HM), spiker (HS), moderatör (TM), yorumcu (TY), uzman konuk (TK/HK), kadın (K), erkek (E).
} 
Toplam 1.238 birimden oluşan çevriyazı metninde birimlerin nerede başlayıp nerede bittiğine tümce ezgisine göre karar verilerek Ölçünlü Türkçeye (ÖT) uygun noktalama işareti eklenmiştir. (Sözel ve sözsüz) bütün ortam sesleri, ekran yazıları ve işitilen sözcüklerle anlamca bağlantılı olan sözsüz görseller de ayrıca not edilmiştir. Çevriyazı metninin yazım, noktalama ve sayısal değerler bakımından üç farklı sürümü bulunmaktadır. ${ }^{3}$ Türkçe ve yabancı dildeki kişi, yer ve kurum adları, bütün sürümlerde ÖT yazım kurallarına uygun olarak yazılmıştır. Birinci ve ikinci sürümde işitilen Türkçe sözcükler işitildiği gibi (örn. diil) yazıya aktarılmış; sayısal değerler de yazıyla ve bağımsız sözcükler biçiminde yazılmıştır (örn. bin dokuz yüz seksen sekiz). İkinci sürüm, birinci sürümün noktalama işaretleri çıkarılmış biçimidir. Üçüncü sürümde ise ölçünlü yazım ve noktalamaya uyulmuş, sayısal değerler rakam olarak yazılmış, yarım kalan sözcükler (toplam 76 adet) ve sesli duraksamalar (SD) (toplam 247 adet) çıkarılmıştır. SD’ler birinci ve ikinci sürümde $e e$ ve $\iota l$ biçiminde yazılmış olup sözcük sayısı (SS), karakter sayısı (KS) ve ortalama sözcük uzunluğu (OSU) (SD dahil/hariç olarak) ayrı ayrı hesaplanmıştır (Tablo 1).

Tablo 1. Çevriyazı Metninin Sürümleri ve Bazı Sayısal Dĕgerler

\begin{tabular}{lcccc}
\hline & SS & boşluklu KS & boşluksuz KS & OSU \\
\hline 1. sürüm & $9.509 / 9.262$ & $68.336 / 67.595$ & $59.848 / 59.354$ & $6,29 / 6,41$ \\
2. sürüm & $9.509 / 9.262$ & $66.792 / 66.051$ & $58.304 / 57.810$ & $6,13 / 6,24$ \\
3. sürüm & $--/ 9.032$ & $--/ 66.505$ & $--/ 58.499$ & $--/ 6,48$ \\
\hline
\end{tabular}

Derlemdeki kesitlerden bazıları seçilerek haber bültenleri ve tartışma programlarındaki ortalama konuşma hızı $(\mathrm{OKH})$ bulunmaya çalışılmıştır (Tablo 2). Tablodaki SS ve OSU değerleri, birinci sürümdeki karakter sayısına göre hesaplanmıştır. OKH, toplam SS (SD hariç) 60'la çarpılıp toplam (saniye cinsinden) kayıt süresine bölünerek bulunmuştur (9.262 sözcük x 60 saniye/ 4.566 saniye $=$ dakikada 121,71 sözcük).

Konuşmaları sözcüğü sözcüğüne aktaran altyazıların okuma-anlama güçlüğü yarattığı bilinmektedir. Geleneksel olarak, rahatça okunabilecek altyazılar için "6 saniye kuralı" (ekranda 6 saniye boyunca tutulan iki satırda toplam 72 karakter içeren altyazı birimi) uygulanmaktadır. Söz gelişi, derlemin sözel içeriği, kısaltılıp yoğunlaştırılmadan, (sayısal değerlerin rakamla

\footnotetext{
3 Özgün sözel içeriğin miktarı ve sunuluş hızı, YS başarımını ve sunulacak altyazıların okunurluğunu doğrudan etkilemektedir. Altyazılamaya özgü yer ve zaman kısıtlarına aşağıda değinilecektir.
} 
yazıldığı, yarım kalan sözcüklerin çıkarıldığı ve ölçünlü yazım ve noktalamanın kullanıldığı) altyazılara dönüştürüldüğü takdirde ortalama 14,57 karakter hızına ulaşılmaktadır (66.505/4.566 sn.). 6 saniye kuralına uygun -yani saniyede 12 karakter hızındaki- altyazılar içinse içeriğin YS aşamasında en az \%18 oranında kısaltılıp yoğunlaştırılması gerekmektedir. Bu durumda YS'de amaç, yalnızca konuşmacıya bağımlı OKT yoluyla doğruluk oranı yüksek, az gecikmeli ve düşük maliyetli CA üretmek değil aynı zamanda özgün sözel metni kısmen düzenleyerek rahatça okunabilecek hız ve biçimde altyazı sunulmasına katkıda bulunmaktır. Aşağıdaki bölümlerde kısaltma/yoğunlaştırma stratejilerine başvurularak gerçekleştirilen bu metin düzenleme işlemini sözdizim, anlambilim/edimbilim ve söylem düzeylerinde etkileyebilecek ögelere odaklanılarak olası sorun ve çözümler tartışılacaktır.

Tablo 2. (1. Sürümdeki Kesintisiz Kesitlere Dayalı Olarak) Ortalama Konuşma $\mathrm{Hizl}$

\begin{tabular}{|c|c|c|c|c|c|c|c|c|}
\hline Türü & $\begin{array}{l}\# \\
\text { Kanal }\end{array}$ & $\begin{array}{l}\# \\
\text { Haber/ } \\
\text { TP }\end{array}$ & $\begin{array}{l}\# \\
\text { Ses }\end{array}$ & $\begin{array}{l}\text { Süre } \\
\text { (sn.) }\end{array}$ & $\begin{array}{l}\text { SS } \\
\text { (SD } \\
\text { dahil) }\end{array}$ & $\begin{array}{l}\mathrm{SS} \\
(\mathrm{SD} \\
\text { hariç})\end{array}$ & $\begin{array}{l}\text { OSU } \\
(\mathrm{SD} \\
\text { hariç) }\end{array}$ & $\begin{array}{l}\mathrm{OKH} \\
(\mathrm{SD} \\
\text { hariç })\end{array}$ \\
\hline $\begin{array}{l}\text { Bütün } \\
\text { derlem }\end{array}$ & 17 & $\begin{array}{l}26 \mathrm{H} / \\
12 \mathrm{TP}\end{array}$ & $\begin{array}{l}47 \mathrm{~K} / \\
48 \mathrm{E}\end{array}$ & 4.566 & 9.509 & 9.262 & 6,41 & 121,71 \\
\hline Haber B. & 10 & 13 & $\begin{array}{l}34 \mathrm{~K} / \\
25 \mathrm{E}\end{array}$ & 1362 & 2.555 & 2.536 & 6,49 & 111,72 \\
\hline Diş ses & 2 & 5 & $\begin{array}{l}2 \mathrm{~K} / \\
3 \mathrm{E}\end{array}$ & 344 & 590 & 590 & 6,81 & 102,91 \\
\hline $\begin{array}{l}\text { Spiker/ } \\
\text { Muhabir }\end{array}$ & 3 & 3 & $\begin{array}{l}1 \mathrm{~K} / \\
2 \mathrm{E}\end{array}$ & 315 & 629 & 611 & 6,66 & 116,38 \\
\hline Ekonomi H. & 2 & 2 & $2 \mathrm{~K}$ & 159 & 334 & 319 & 6,87 & 120,38 \\
\hline Moderatör & 3 & 3 & $\begin{array}{l}2 \mathrm{~K} / \\
1 \mathrm{E}\end{array}$ & 284 & 685 & 646 & 6,09 & 136,48 \\
\hline $\begin{array}{l}\text { Konuk/ } \\
\text { yorumcu }\end{array}$ & 8 & 13 & $\begin{array}{l}4 \mathrm{~K} / \\
12 \mathrm{E}\end{array}$ & 1567 & 3330 & 3220 & 6,22 & 123,29 \\
\hline $\begin{array}{l}\text { TP } \\
\text { (örtüşmeli) }\end{array}$ & 1 & 1 & $3 \mathrm{E}$ & 295 & 740 & 712 & 6,00 & 144,81 \\
\hline
\end{tabular}

\section{Sözdizim Düzeyinde Gözlemler}

YS’yi tümce düzeyinde etkileyebilecek üç nokta saptanmıştır: (i) tümce uzunluğu, (ii) sözcük dizilişi ve etki alanı ve (iii) dilbilgisel olmayan veya çeşitli nedenlerle anlatım bozukluğu içeren yapılar (örn. yarım bırakılmış 
yapılar; yineleme veya onarım yoluyla başka biçimde yeniden kurulmuş tümceler). Ses-görüntü-altyazı uyumsuzluğuna neden olmamak için zaman baskısı altında çalışan YS görevlisi, bir yandan ardışık olarak işittiği özgün tümceleri belleğinde tutarken bir yandan da o tümceleri anlam yitimine yol açmadan yeniden düzenlenmiş biçimde seslendirmek durumundadır. İşleyen belleğin sınırlı olduğu ve YS sırasında dikkatin aynı anda birden fazla göreve bölündüğü düşünülürse, bu tür yapıların, YS görevlisi açısından anlama, anımsama veya yeniden biçimlendirme güçlüğü yaratabileceği kestirilebilir.

\subsection{Tümce Uzunluğu}

Derlemdeki 1.238 birimin 1.202'si (\%97,09) 1-20 sözcükten oluşmakta olup 21-46 sözcükten oluşan birim sayısı ise 36'dır (\%2,91). 2-9 sözcükten oluşan birim sayısı ise $899(\% 72,62)$ olarak hesaplanmıştır (Şekil 1).

Şekil 1. Birim Başına Düşen Sözcük Sayısı (1. Sürüme Dayalı Olarak)

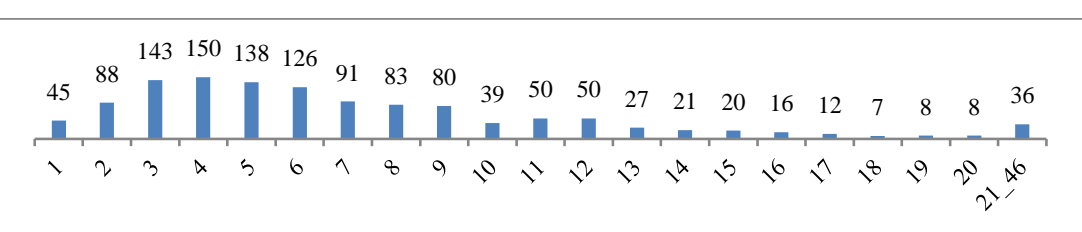

Derlemde sık görülmese de uzun tümceler, hem konuşmacı hem de YS görevlisi açısından işlemleme güçlüğü yaratabilir. 46 sözcük içeren (1)'deki konuşmacı, tümcenin başında devletimizin sözcüğünü kullanmış olsa da edilgen yapıyla (belirlenmesi, ödenmesine karar verilmesi) devam etmiştir. Yapısal açıdan dilbilgisellik sağlanamamış olsa da anlam düzeyinde bir onarım söz konusudur: Konuşmacı, bilgi yanlışını düzeltmeyi öncelemiştir çünkü kararı veren devlet değil AYM'dir. Özgün içerik YS'de sözcüğü sözcügüne aktarıldığı takdirde bu sözdizimsel sorun aynen kalacaktır. Donanımlı bir YS görevlisi tümcenin tamamını dinledikten sonra kısaltma/yoğunlaştırma yaparken devletimizin sözcügünü çıkararak sorunu çözebilecek olsa da özgün tümce toplam 25 saniye sürdügünden gecikme önlenemeyecektir. Anlam/bilgi yitimine neden olunmadan atlanabilecek sözcükler (1)'de (ve sonraki örneklerde) yatık yazıyla verilmiştir. ${ }^{4}$

\footnotetext{
${ }^{4}$ Örneklerde 1. sürüm temel alınmış; ancak okuma kolaylığı açısından sayısal değerler ve tarihler rakamla yazılmıştır (örn. (32)'de bin dokuz yüz seksenlerde yerine 1980'lerde). Bu nedenle, toplam 138 boşluksuz karakterden oluşan 32 sözcük, 46 karakterlik yer kaplayan 16 sözcüğe dönüşmüştür.
} 
(1) Ama ne olursa olsun, devletimizin böyle bir haksızlık karşısında barış akademisyenlerinin hem suçsuzluğunun belirlenmesi hem de bunlara yapılan haksızlıktan dolayı bir tazminat ödenmesine karar verilmesi gene bu dönemde tırnak içinde, bu dönemde, bu adaletsiz ve hukuksuz dönemde, Anayasa Mahkemesi’nin göğsüne takılan bir madalya olarak tarihte anılacaktır. (TY-E-3)

Benzer bir sorun, (2c)'de de görülmektedir. Bu tümce, yarım bırakılmış bir yapının (2b) ardından başlamakta olup SD'ler ve yarım sözcük ( $g e$-) dışında 45 sözcükten oluşmaktadır. Ayrıca, çok sayıda -DIK ortaçlı yapı içeren bir zaman ifadesi (... bir dönemde) ile amaç belirten bir yapı (... arzusuyla) içermektedir. $\mathrm{Bu}$ tümceyi kuran milletvekili, aynı zamanda hukukçudur. Böyle bir kişinin mesleki becerisine ve siyasetçi olarak doğaçlama konuşma deneyimine güvendiği varsayılabilir. Ancak -DIK ortacıyla özne (akademisyenlerin ... hareket geçtiği bir bildiri) arasındaki anlamsal bağ tam olarak kurulamamıştır. Yapının ((arzusuyla) hazırladığı/harekete geçtiği bir dönemde hazırlanmış (bir bildiri)) olarak düzenlenebilmesi içinse hem güçlü bir kısa süreli bellek hem de konuya en üst düzeyde hakimiyet gerekmektedir.

(2) a. Fakat işi bağlamında, konuyu bağlamında değerlendirmek lazım.

b. Bu bildirinin yayınlandı̆̆ dönem-

c. Terör örgütünün ee sıkıştı̆̆ı ee bazı ee ilçe merkezlerimizde hendekler açtığ1 ama ee güvenlik güçlerimizin operasyonlarıyla ee zor durumda kaldığı, terör örgütünün ee ciddi ölçüde zaafa uğratıldığı bir dönemde, sıkıştı̆̆ bir dönemde, bir alandan akademisyenlerin ona bir çıkış, ulusal ve uluslararası gündemde bir çıkış sağlama arzusuyla harekete ge- geçtiği ee bir bildiriden bahsediyoruz. (TK-E-1)

Bültenlerde de uzun tümceler bulunmakta olup özellikle dış kaynaklı haberlerde yazı dilini yansıtan çeviri metinler yer alabilmektedir. Uluslararası kredi derecelendirme kuruluşu S\&P'nin bir açıklamasından bahsedilen (3)'te (1) ve (2)'deki gibi bilgi yitimine neden olmadan atlanabilecek sözcükler bulunmamaktadır. Boşluklu 341 karakterlik yer kaplayan 36 sözcüklük bu tümce, 4 ardışık iki satırlık altyazı birimine bile sığmayacaktır. İzleyicilerin bu kadar karmaşık ve terim içeren bir tümceyi belleğinde tutup anlayabileceği kuşkuludur. Yantümcelerin anlam bütünlüğü bozulmadan bağımsız ana tümcelere dönüştürülmesi içinse tümcenin tamamının dinlenip anlaşılmış olması gereklidir. Bu da gecikmeye neden olacaktır. Öyleyse, herkes için daha 
anlaşılır haber için (3) gibi tümcelerin haber üretimi sırasında farkedilip konuşma diline uygun hale getirilmesi gerekmektedir. ${ }^{5}$

(3) $\mathrm{ABD}$ ve Çin arasındaki kırılgan ekonomik ateşkes nedeniyle, gelişen ekonomilerde koşulların zorlaşabileceği belirtilen açıklamada, Amerika'nın korumacı politika önlemleri, gelişen ekonomilerdeki zayıflayan ekonomik veriler ve jeopolitik risklerin gelişen ekonomilerin büyüme görünümleri üzerinde bask1 oluşturması, riskler arasında siralandi. (HE-K-2)

\subsection{Sözcük Dizilişi ve Etki Alanı}

Sözcük dizilişinin değişken oluşu, özellikle niteleyicilerden kaynaklanan etki alanı sorunları ortaya çıkarabilmektedir. (4)'teki matematik öğretmeni, çocuklardaki matematik korkusunu yenmek için dersinde kullandığı karikatürlerden bahsetmektedir. Ancak, her türlü niteleyicisi, etkinlik değil de ders sözcüğünden önce geldiği için öğretmenin matematik dışındaki derslere de girdiği düşünülebilir. (5)'te bir ad öbeğinden önce gelen çok da fazla ifadesininse hangi eylemi nitelediği belli değildir (yaklaş-, yakınlaş-, arzu et-). Aşağıda (13)'te ise derhal belirteci ceza ver- eyleminden önce değil asıl nitelediği serbest birak- eyleminden önce gelmelidir.

(4) Bu önyargıyı ve korkuyu yıkmak adına etkinlikler, oyunlar, her türlü ders içersinde yapiyoruz. (K, HB10)

(5) Çünkü Amerika çok da fazla PYD’nin Şam'a yaklaşmasını yani Rusya’ya yakınlaşmasını çok arzu etmiyor. (TK-E-5)

Sözcük dizilişi, bilgi yapısına bağlı olarak, odak vurgusu sorununa da yol açabilmektedir. (6c)'de odaklanan, eylemden hemen önce gelen kurucudur (Anayasa Mahkemesi). Oysa, (6a)'da AYM'nin kararından bahsedildiğine göre,

\footnotetext{
${ }^{5}$ Haber bültenlerinin büyük bölümü belirli bir metne dayalı olarak kurgulanmış olup metni bulunmayan içerik, görüşülen kişilerin ve uzaktan bağlanan muhabirlerin konuşmalarından ibarettir. $\mathrm{Bu}$ nedenle, metne dayalı içerik için önceden altyazı hazırlanarak bülten sırasında canlı olarak yayına verilebilmekte; metni olmayan içerikse YS yoluyla eklenebilmektedir. Yarı-canlı altyazılama adı verilen bu yöntemin sakıncası, okunamayacak kadar hızlı altyazılara yol açmasıdır. Romero-Fresco (2016)'ya göre, haber programlarında dakikada 152 sözcük hızında altyazı sunulduğunda izleyiciler zamanlarının yarısını görüntülere bakarak yarısını da altyazı okuyarak geçirebilmektedir. Yarı-canlı uygulamalarda ise önceden hazırlanmış altyazılar (YS aşamasında ortaya çıkan gecikmeyi azaltabilmek amacıyla) hızla yayına verildiğinden dakikada 360 ila 1500 sözcük hızında altyazılara rastlanılmıştır (s. 65).
} 
(6c)'de AYM eski bilgi olarak konulaştırılmalı; ifade hürriyeti bağlamında ise yeni bilgi olarak vurgulanmalidır.

(6) a. Yani Anayasa Mahkemesi'nin kararının nihai halini ee doğru bulmuyorum.

b. Şun'için bunu ee söylüyorum.

c. Ee ifade hürriyeti bağlamında Anayasa Mahkemesi değerlendirmiş. (TK-E-1)

\subsection{Anlatım Bozukluklarl ve Onarım}

TV ortamında konuşmacıların hiç duraksamadan, akıcı biçimde konuşmaları beklense de başta canlı yayın heyecanı olmak üzere çeșitli nedenlerle tümceler kesintiye uğrayabilmektedir. Bu durumlarda konuşmacılar çeşitli yöntemlerle kendi kendilerini düzeltme ve varsa bozuk yapıları onarma yoluna gitmektedir. Aşağıdaki örneklerde temelde tümce düzeyinde oluşmuş olsalar da anlam ve söylem açısından da değerlendirilmesi gereken çokboyutlu anlatım bozukluklarına yer verilmiştir.

(7)'deki dikkati dağılmış görünen moderatör, konuşma sırası gelen konuğu yönlendirmek için tahminen (Nedir bu meselede bizi bu kadar ayrıştıran?) demek istese de birden fazla sorun (SD, yarım kalmış sözcük (bi-), yineleme (mesele) ve yeri yanlış niteleyici (bu kadar)) barındıran tümceyi onaramamıştır. (8b)'de İngilizce teknik bir terim kullanan konuşmacıysa, hem Türkçe terimi anımsayıp belirtmek hem de terimi açıklayan bilgiler eklemek durumunda kalmıştır. Bu da yarım bırakılmış sözcüklere (dedim-, biyo-), çok sayıda SD’ye ve yeni bir tümce kurulmasına (hepsinin alınması lazımdı) yol açmıştır.

(7) Nedir bi- bu kadar bu meselede ee bizi ayrıştıran? Mesele? (TM-K-1)

(8) a. Yani bi defa başlangıçtan itibaren giren herkesin.

b. ee biyo-ee intelicıns dedim-biyo-biyometrik dediğimiz ee işte göz bebekleri ee el.

c. ee avuç izleri, parmak izleri ee hepsinin alınması lazımdı. (TK-E-3)

Yanlış sözcük seçimleri de bozukluğa neden olabilmektedir. (9)'da önce çıkarına sözcüğü kullanılsa da tümcenin devamında işine gel- deyimiyle düzeltme yapılmıştır. (10a)'da ise değerlendir- uygun yapı içinde (örn. AYM, bildiriyi düşünce ve ifade açıklama özgürlüğ̈̈ kapsamında değerlendirdi.) kullanılmamıştır. (10b)'deki kamu sözcüğünün de neden seçildiği anlaşılmamaktadır.

(9) Ama Amerika'nın çıkarına orda daha manipüle edebileceği bir gücün olması işine gelicek diye düşünüyorum. (TK-E-5) 
(10) a. Ee 26 Temmuz tarihinde Yüksek Mahkeme söz konusu bildirinin düşünce ve ifade açıklama özgürlüğü kapsamında olduğunu değerlendirdi.

b. Kaтиуи ee ee değerlendirdi. (HM-E)

Anlatım bozukluklarının bir başka nedeniyse başta yantümcelerdekiler olmak üzere yanlış ya da eksik çekim ekleridir. Bunlardan bazıları farkedilmezken $(11,12)$ bazılarıysa onarılmıştır (13). İstanbul valisinin sözlerinin aktarıldığı (11)'de kavram-terim karmaşası (kayıtsız göçmen, belirli bir kentte kayıtlı olan göçmen, kayıtlı bulunduğu kent yerine İstanbul'da bulunan göçmen) anlatım güçlüğü yaratmıştır. (11b)'deki yapının (kayıtlı olan yer) dilbilgisel olması için edilgen yapıya başvurularak kayıtlı olunan yer ya da $-(y) A n$ ortacı yerine $-D I K$ ortacı kullanılarak kayıtlı oldukları yer biçiminde düzeltilmesi gerekmektedir. Gönder- eyleminin nesnesi (Suriyeliler) ise - $(y) I$ belirtme eki yerine tamlayan eki taşımaktadır. (11b)'deki ikinci hedefinin diye başlayan ve (11a)'daki yapıya koşut biçimde sonlanması beklenen (... olduğundan bahsetti) yap1 da tamamlanmamıştır. Eksik ek örneği olaraksa aşağıda (41b)'deki arasında ilgecinin gerektirdiği tamlayan eki verilebilir.

(11) a. Birinci hedefin düzensiz göçü bitirmek olduğundan bahsetti.

b. İkinci hedefinin de başka yere kayıtlı olan ee İstanbul'daki Suriyelilerin kayıtlı olan ee yerlere göndermek. (TM-K-1)

Olağan sözcük dizilişinde yüklemin sonda olması nedeniyle, yükleme gelindiğinde gerçekleştirilen onarım, önceden söylenmiş bulunan özne ve nesne eklerinin yüklemle uyumsuz olmasına neden olabilmektedir. (12) bu rehberde diye başladığı için yüklemin (öngör-) edilgen olması beklenebilir. Oysa, ad görevli yantümce (... çekil-me-si-ni) belirtili nesne olarak etken eyleme bağlanmiştır.

(12) $\imath$ bu rehberde Hazine'nin elindeki bütün taşınmazların yatırımcılara ee doğrudan ee işte peşkeş çekilmesini öngörüyor. (TK-K-2)

Kendi sözlerini dinleyerek denetleyen konuşmacılarsa eklerden kaynaklanan sorunları giderebilmektedir. (13)'te özgürlük yinelenerek ad görevli yantümcenin eylemi zedelen- için gereken tamlayan eki - $(n) I n$ eklenmiştir. Öden- eyleminin zaman/görünüş eki yarıda kesilerek yantümceye uygun adlaştırma $(-m A)$ ve durum eki $(-(y) A)$ eklenmiştir. 
(13) Efenim ee bunların ee fikir özgürlüklerine, ifade özgürlüklerinin zedelendiğine ee karar veren Anayasa Mahkemesi, hem haklarında verilen cezaların hükümsüz olduğunu ilan ediyor -ki derhal bu konuda ceza verilip hapse atılanlar serbest bırakılmalı hâlâ kaldıysa içerde- hem de 9 bin lira bunlara tazminat ödene- ödenmesine karar veriyor. (TY-E-3)

Konuşma hızının yükseldiği durumlardaysa konuşmacıların kendi sözlerini denetlemeleri güçleşmektedir. Toplam 49 sözcüğün 15,5 saniye içinde seslendirildiği (dakikada 189,68 sözcük) (14)'te yapısal ve anlamsal bozukluk oluşmuştur. (14b)'deki yapı (yıldızla gösterilen noktada) yarım bırakılarak başka bir tümceyle devam edilmiştir. Bu iki yapı arasında sadece 100 salise sessizlik olup demek de'den sonra biten ezgi işitilmemektedir. (14c-d-e)'deki benzerlik gösteren $d A$ kullanımı, olumlu soru yapısıyla kabul edilebilir değildir. (14b)'deki anlam (Türkiye, bir Kürt bölgesi istemez.) olumsuz olduğuna göre benzerlik ilişkisinin kurulabilmesi için olumsuz bir bildirme tümcesi (Irak $d a$ buпи istemez.) gerekmektedir. Amaç, öteki tarafların ne istediğini sorgulamaksa tümce $d A$ olmadan kurulabilir (örn. Irak bunu ister mi?). (14e)'deyse hem $d A$ hem de $m I$ soru parçacığının yeri nedeniyle yanlış sezdirim doğmuştur (öteki taraflar gibi Suriye de).

(14) a. Bizim açımızdan önemli şey, Suriye'nin bir federal yap1 değil üniter yap1 olmas1.

b. Federal yapı olmaması demek de * kuzeyinde bir Kürt bölgesi olması Türkiye'nin çok istiyceği bişey diil.

c. Acaba bunu Irak tarafi $d a$ ister mi?

d. Ruslar $d a$ ister mi?

e. Suriye de mi ister?

f. İstemez.

g. Sadece Amerika ister bence böyle bişeyi. (TK-E-5)

Derlemde birden fazla anlatım bozukluğu görülen örneklere de rastlanılmıştır $(15,16)$. (15a)'da (yineleme ya da sürerlik gösterebilen) bitmemişlik eki (I)yor, bir durum eylemiyle (sahip oluyodu) kullanılmıştır. (15d)'de ödünleme gösteren -sA bile ile karşıtlık gösteren ama bir aradadır. (Türkiye'deki göçmen nüfus oranına yakın olmasa $d a$ ) biçiminde anlaşılması gereken (15d)'deki neredeyse belirtecinin gerekli olup olmadığı ya da hangi ögeyi nitelediği belli değildir. 
(15) a. Bir ara işte Afganistan Rusya işgalinde, Pakistan çok ciddi bir ee göçmen nüfusuna sahip oluyodu.

b. Işste bu ara Myanmar'daki hadiselerden dolayı Bangladeş aynı şekilde.

c. Ve Ürdün.

d. Suriye meselesinden dolayı neredeyse Türkiye'yle yakın olmasa bile ama nüfusu oranında ciddi anlamda bir göçmen nüfusuna sahip. (TKE-4)

(16)'daki bağlamda, Avrupa Merkez Bankası'nın açıklamasında yer alan üç nokta aktarılmaktadır (büyümede düşme, enflasyon hedefinin tutmama olasılığ1 ve faiz indirimi olasılığı). (16a)'daki tümcenin öznesi, (tamlayanı bir tümce olan (... artmayacak)) beklentisi sözcüğüyle oluşturulan ad tamlaması olup gelbu özneye uygun bir yüklem değildir. Sonradan eklenen faiz indirimi ad öbeği de gelmiş durumda yüklemiyle yanlış bilgi içermektedir (Faiz indirimi yapılmamıştır.). Bu sorunu çözmek için (16b) eklenerek (sonradan akla gelen, odaksıl olmayan ek bilgiyi yüklem sonrasına bırakma olanağından yararlanılarak) (16a)'daki yükleme bağlanmaya çalışılmıştır; (16a) ile (16b) arasındaki sessiz boşluk sadece 70 salisedir.

(16) a. Dolayısıyla $l l$ büyüme tahminleri aşağıya inerken enflasyon çok artmıcak beklentisi Avrupa Merkez Bankası'dan faiz indirimi önümüzdeki aylara ilişkin, eylül ayına ilişkin gelmiş durumda.

b. Faiz indirimi mesaj1. (HE-K-1)

(15) ve (16)'nın ortak özelliği, aynı anda birden fazla kavramın ifade edilmeye çalışılması olabilir ((15d)'de neden (-DAn dolayı), karşılaştırma (Ürdün ve Türkiye'deki göçmen sayısı) ve karşıtlık; (16a)'da karşıtlık ve beklenmezlik (büyüme düşerken enflasyonun yükselmemesi). Farklı özellikleriyse (15)'teki konuşmacının onarıma gerek duymazken (16)'dakinin tümceyi kurtarmaya çalışmış olmasıdır. (17)'de de iki farklı soruna karşın (17a)'daki bilgi (17b)'de başka bir biçimde yeniden sunularak yapı onarılmıştır. (17a)'da etki alanı sorunu yaratan hemen, aynı tümce içinde (şimdi eklenmiş biçimde) yinelenerek nitelediği eyleme yaklaştırılmıştır. Koşul yapısı barındırmayan (17a)'daki eğer ise (17b)'de doğru biçimde (koşul yapısını pekiştirmek amacıyla) kullanmıştır.

(17) a. Ve hemen tutuklu bütün barış akademisyenlerinin ĕger cezaevinde olanlarının hemen şimdi infazlarının durdurulması gerekiyor.

b. Önce infazlar durdurulmalı ve eğer tutuklu veya hapishanede olanlar varsa serbest birakılmalıdır. (TY-E-4) 


\section{Anlambilim/Edimbilim Düzeyinde Gözlemler}

Derlemde YS'yi anlambilim/edimbilim düzeyinde etkileyebilecek şu noktalarla karşılaşılmıştır: (i) tümcenin kipi (bildirme, emir/dilek ya da soru), (ii) sözeylemler, (iii) kiplik yapıları ve (iv) konuşmacıların konuya/duruma karşı takındıkları tutumlar.

\subsection{Kip ve Sözeylem}

Haber/bilgi içeriğinin bir sonucu olarak, derlemdeki tümcelerin çoğu bildirme tümceleridir. Dikkat çekmek için bak(ın) sözcüğüne başvurulan yapılar dışında (24a, 26c, 42d, 63i) 2. kişi emir çekimi bulunmamaktadır; 1. kişi - $(y) A$ istek ekli yapılara örnek olarak (19b, 19g, 22a, 23a, 26e) verilebilir. Soru tümceleri de azınlıkta olup konuyu anlaşılır kılmak ya da izleyicilerin dikkatini yönlendirmek amacını taşımaktadır. (18)'deki nörolog, kendi kendine soru sorup yanıtlayarak $(18 \mathrm{~b}, \mathrm{f})$, tıp terimlerini gündelik dildeki sözcüklerle açıklayıp arkaplan bilgisi ekleyerek (18c, h, i) ve kullandığı yapıları yineleyerek (18d-e, i) izleyicinin ilgisini sürdürmeye çalışmaktadır. (19)'da ise önce retorik bir soruyla izleyicilerin ve öteki katılımcıların dikkatleri ilgili konuya çekilmiş (19a); sonra da izleyiciye bilgi verilmese de üç soruyla (19c-de) anımsamaları gereken noktalar sıralanmıştır (Bkz. 14c-d-e). ${ }^{6}$

(18) a. Bi kere organizasyon sistemi farklı kadın ve erkek beyninin.

b. Nedir bu?

c. $O$ nöron ağları, hani her bir nöronun birbiriyle bağlantı yaptığı kablolar.

d. Kadın beyninde farklı organize olmuş.

e. Erkek beyninde farklı organize olmuş.

f. Ne demek istiyorum?

g. Erkek beyninde tek $b$ -

h. Bizim beynimiz ikiye ayrılmıştır biliyorsunuz.

i. Sağ beyin sol beyin, sağ lob sol lob gibi. (TK-K-1)

(19) a. Ama şunu hatırlamakta fayda yok mu?

b. Erbil'e bakalım.

c. Irak'1n kuzeyi biz ee 1980'lerde nerdeydik?

d. Erbil ne durumdaydi?

e. Barzani Talabani'ye nasil bakıyoduk?

f. Sonra Bağdat'ı reddedip Erbil'le görüşmeye başladık.

g. Bunu unutmayalım. (TK-E-5)

6 (19a), konuşmacının ilk tümcesidir. Konuşması sırası başkasında olduğu halde moderatörü beklemeden kendi kendine konuşma sırası alarak tartışmaya katılmıştır. 
Derlemde çok az sayıda sözeylem örneğine rastlanılmıştır. Bunlardan bazıları dolaylı, bazılarıysa ilgili sözcüğü içeren ifadelerdir (izin, teşekkür, rica). (20)'de birinci yorumcu, (aynı zamanda kanalın sahibi olan) ikinci yorumcudan biraz daha konuşmak için dolaylı biçimde ek süre istemektedir. İkinci yorumcu da (21b)'de sayg1 (hocam) ve izin (buyrun) ifade eden incelik (lütfen) yapılarını kullanmıştır.

(20) Şimdi hemen hızla Anayasa Mahkemesi'nin barış akademisyenleri davasına bişiy söyleyip size aktarıyorum. (TY-E-3)

(21) Tabii hocam, buyrun lütfen. (TY-E-4)

TV ortamındaki bazı yapılar, sözeylemin ötesinde bir işlev taşımaktadır. (22a)'daki rica edeyim (döndür- eylemi olmasa da) yapısının amacı, kameranın tabloya döndürülmesini sağlamaktadır. (22d)'deki dönmek istiyorum da uzman konuğun görüntülenmesini sağlamak için söylenmiştir. Bu açıdan, dolaylı bir sözeylemin gerçekleştiği düşünülebilir. (23)'te ise (başta 1. çoğul kişi çekimi olmak üzere) izleyiciyle bağ kurmaya yarayan yapılar şöyledir: (23a)'da sosyal medyadan gönderilen iletinin okunacağını bildirme, (23c-d-e)'de iletisi ekrana yansıtılıp okunan izleyiciye yönelik iltifatlar ve (23f)'de (kurum adına) teşekkür.

(22) a. Şimdi ben kameraman arkadaşım ... 'den rica edeyim.

b. Yanımızda bi tablo var aslında vatandaşların daha iyi anlayabilmesi için.

c. Bu tablo üzerinden tek tek anlaticaz.

d. Ben hemen ee ...'e dönmek istiyorum.

e. Sayın ... nedir bu tablonun detayları? (muhabir (E), AHABER_2507)

(23) a. Son bi mesaj okuyalım.

b. Ee "bence güzellik görünüşünüz neye benzerse benzesin nezaket sizi dünyanın en güzeli yapar" demiş.

c. İmzamı atarim.

d. Sonuna dek kat1liyorum.

e. Çok güzel yazmışsınız.

f. Teşekkür ederiz. (TM-K-2)

Yukarıdaki örneklerin YS aşamasında kısaltılıp yoğunlaştırılması için farklı stratejilerin uygulanması gerekebilir. (18-23)'te yatık yazıların çıkarılması anlamı bozmayacaktır. (18d-e)'de yineleme yerine eşbağlamaya başvurulabilir (erkek ve kadın beyninde). (19b-c-d)'de artıklık giderilerek tek bir tümce elde edilebilir (örn. 1980'lerde Erbil konusunda neredeydik?). (23b)'deki ileti zaten 
ekranın sağ üst köşesinde görüntülendiği için gecikme söz konusuysa tamamen çıkarılabilir.

\subsection{Kiplik ve Tutum}

Derlemdeki konuşmacıların, özellikle de siyasal konularda yorum yapanların olabildiğince tarafsız kalmaya çalışarak kişisel tutum ve yargılarını yansıtmaktan kaçındıkları görülmektedir. Sözcük değiştirmek gibi basit yöntemlerin yanısıra Türkçenin sunduğu daha kapsamlı sözcüksel ve dilbilgisel olanaklardan da yararlanılmıştır.

(24) ve (26)'da emekli bir siyasetçi, sosyal medyada önemli bir devlet görevlisine ait olduğu belirtilen sözlerin bilgisayar çıktısını göstererek bu sözlerin yalanlanması gerektiğini vurgulamaktadır. Yansız tutum göstermeye yarayan kiplik ifadelerinden bazıları sözcüksel (emin değilim (24b), ona atfen (24e), hiç ihtimal vermiyorum ... (26h-i)) bazıları ise dilbilgiseldir (demiş (24g), dememiş olsun (25), (inşallah ...) yalandır (26c-d)).

(24) a. Bakın bu laf-

b. Şu lafları sayın ...'nın söyleyip söylemediğinden emin değilim.

c. Daha önce, çeşitli vesilelerle de tekrarladım.

d. Ve bir açıklama yapılmasını bekliyorum.

e. Yani şu anda da, bu 2 demeç ona atfen, sosyal medyada var.

f. Yalanlanmadi.

g. Mesela demiş ki ... (TY-E-1)

(25) E artık bunu da dememiș olsun. (yorumcu (E), HALKTV 3007)

(26) a. Ama bunu- yeni değil bu.

b. Son 7-8 ay öncesi söylenen laf olarak.

c. İnşallah diyorum bak.

d. Yalandir.

e. Ama yalanlasınlar kardeşim.

f. A bu da d-dehşet.

g. "..."

h. Ben buna hiç ihtimal vermiyorum.

i. $\quad B$ - böyle bir sözü söylediğine. (TY-E-1)

Buna benzer bir yaklaşım, Suriyeliler konusunda söz alan hukukçuda da görülmektedir $(27,28)$. (27)'nin bağlamında, yinelenen yerel seçimlerin ardından İstanbul'daki Suriyeliler konusunda iktidara yöneltilen eleştiriler tartışılmaktadır. Konuşmacı, iğneleme olarak anlaşılabilecek sözlerini herhalde ... değildir ve diye düşünüyorum ile yumuşatmıştır. (28)' de ise tahminen espri mahiyetinde olsun/olsa da diyecekken tümceyi yeniden kurarak onarmıştır. Böylece hem yansızlığını korumuş (siz karar verin (28b)), hem sorunu şakaya 
vurarak önemsizleştirmemiş, hem de Suriyelilere tanınan (28c)'deki gibi ayrıcalıkların mülteci hukukunda yeri olmadığını sezdirmiştir. (28c) zaten ince alay barındırmaktadır.

(27) ... Hanım herhalde İstanbul Belediye seçim sonuçlarından dolayı değildir diye düşünüyorum. (TK-E-2)

(28) a. Ayrıca yeri gelmişken söyliyim.

b. Bi espri mahiyetinde ols- $o$ - olup olmadığına siz karar verin.

c. Hiçbir mülteci de bayramda memleketine gidip de geri gelmez. (TK-E2)

Derlemde Yemenici (1999)'daki bulgulara benzer biçimde kaçamak ifadelere de rastlanılmıştır. Bir emekli büyükelçi (TP-TK-E-7), tahminen devlet sırrı olarak değerlendirilebilecek bilgileri açık etmemek ya da bazı kesimleri eleştiriyor durumuna düşmemek için lafı dolandırmaktadır $(29,32,36,38,41)$. Moderatör (TP-TM-E-2) $(31,33,35,37,40)$ ve emekli general olan bir başka konuk da (TP-TK-E-3) $(30,34,39)$ zaman zaman örtüşmeli olsa da büyükelçiyi destekler biçimde konuşmaktadır. Büyükelçi (36a)'da konu ABD'ye geldiğinde sözünü yarıda kesmiş; (36b)'deyse (moderatöre manidar biçimde gülümseyerek) konuyu değiştirmeye çalışmıştır. Aynı kaçamak tutum (38)'de de görülmektedir. Dili en üst düzeyde kullanmak üzere eğitilmiş bir diplomatın bu denli tutuk olmasının başka bir açıklaması olamaz. Konu öteki katılımcılar tarafından (39) ve (40)'ta açıkça dile getirildikten sonra büyükelçi (41)'de daha net konuşabilmiştir.

(29) Ee Suriye'de $b u$ - bütün bu tarihi gelişim olmadığg gibi Suriye'deki ee Kürt oluşumu PKK'yla direk olarak bağlantıl1.

(30) Direk PKK'nın kurduğu bir o-

(31) PKK kurdu zaten

(32) PKK'nın kurduğu yani 1982'de biliyorsunuz

(33) Ama Türkiye muhatap aldı efenim uzun uzun zaman yani ee

(34) Maalesef

(35) Ee bunun başındaki insan Türkiye'ye geldi. Ağarlandı. Gitti, geldi falan yani.

(36) a. Işte o stralarda yani Ame- yani herhalde Türkiye ee tabii yani ee Suriye sorunun hepsine, başına baktığımız zaman.

b. O ayrı bir program herhalde.

(37) $S a$ - $s a$ - Salih Müslim sürekli burdaydı. 
(38) a. Evet o dönemlerde.

b. Ee herhalde Türkiye de işte bunlarla.

c. Ee belirli bir şey içersinde.

d. Ee o dönemde çünkü Türkiye'de de başka bir süreç işliyordu anladığım kadarıyla.

e. Farklı bir süreç vardı.

(39) Açılım süreci.

(40) Açılım vardı o zaman.

(41) a. Açılım vardı.

b. O iki arasında bi ilişki vardı. ...

c. Ben Irak özel temsilcisiydim o dönemlerde.

\section{Söylem Düzeyinde Gözlemler ve Kısaltma/Yoğunlaştırma Stratejileri}

Derlemdeki dilsel veriler yukarıdaki bölümlerde ağırlıklı olarak yapısal, anlamsal ve edimsel yönden değerlendirilmiştir. Öte yandan, haber bültenleri ve tartışma programlarıyla ilgili genel bir arkaplan bilgisi varsayılmış; dil kesitlerinin söylemin bütünündeki yeri, konuşma ortamındaki öteki katılımcıların sözleri ya da dildışı durum bağlamı ele alınamamıştır. Bunun bir nedeni yer kısıtı olsa da asıl neden, OKH'nin alt sınırını hesaplayabilmek için karşılıklı konuşmaların olmadığı, örtüşmesiz kesitlere öncelik tanınmış olmasıdır. ${ }^{7} \mathrm{Bu}$ bölümde, doğal konuşmalarda sıkça gözlemlenmekle beraber doğrudan bilgi aktarmak amacıyla kullanılmayan çeşitli ögeler, YS açısından değerlendirilerek atlama ve yeniden biçimlendirme stratejilerinden hangisine hangi durum(lar)da öncelik tanınabileceği saptanmaya çalışılacaktır.

\subsection{Atlama}

Derlemin geneline bakıldığında, bilgi yitimine yol açmadan atlanabilecek ögeler şöyle sıralanabilir:

(i) Sesli duraksamalar: Sözcüksel içeriği olmayıp /a:, ع:, u:/ biçiminde işitilen SD'ler bağlama bakılmaksızın atlanmaktadır. SD'lerden farklı bir tonlamayla, /E/ $(25,53)$ ve /a/ (26f) olarak işitilenlerse daha renkli bir sözlü anlatım sağlasa da altyazıda bürünsel özellikler gösterilemediğinden yazım yanlışı olarak algılanabilir. Kastedilen anlam bağlamdan kestirilebildiğinden bu ögeler de atlanabilir.

\footnotetext{
7 Örtüşmeli konuşmalar, YS görevlisi açısından hem işlemleme hem de seçim sorunudur: dikkatini yoğunlaştırdığı tek bir konuşmacının sesini ayrıştırıp dediklerini aktarabilse bile yansız davranamamış olacaktır. Üstelik, birden fazla kişinin sözlerinin tamamı yazıya aktarılabilse bile izleyicilerin okuma hızı aşılacaktır.
} 
(ii) Dolgu sözcükleri: Dolgu sözcüklerinin başında anımsanamayan ad öbeklerinin yerini tutan şey/bir şey $(38 \mathrm{c}, 14)$ gelmektedir. Aşağıda söylem belirleyicileri arasında ele alınacak yani ve işte de bir kurucunun yerine konulmasalar da bazen aranan sözcük anımsanana kadar zaman kazanmak amacıyla kullanılabilmektedir (örn. 8b, 12, 15, 38b, 43c, 45a/b'de işte). (42d)'de kastedilen, konuşmanın devamında açıkça söylenmese de Lübnan anayasasının bazı özellikleridir. (43) ve (45)'te dikkatini toparlayamayan konuşmacı, kendisinden önce konuşan cerrahın sıraladığı beden bölümlerini anımsamakta güçlük çekmektedir; eliyle kendi elmacık kemiklerini gösterirken cerrah araya girmiş ve (44) ile (45a) örtüşmeli olarak işitilmiştir. Bir kurucunun yerini tuttuğundan $(42 \mathrm{c}, 42 \mathrm{~d}, 43 \mathrm{~b}, 45 \mathrm{c})$ şey'in çıkarılabilmesi için bütün tümcenin atlanması gerekebilir (42c, 45c).

(42) a. Ve 2005 anayasasının içersinde maalesef başka hatalar da yapıldı.

b. Sadece Kuzey'deki Kürt bölgesi diil.

c. Yani onlara biz şeyi de söyledik.

d. Dedik ki "bakın Lübnan'daki şeyi alıyorsunuz." (TP-TK-E-7)

(43) a. Bi de yeni normal diye bi kavram var.

b. Yani ee bu çă̆an gerektirdiği, bu çă̆an özelliği, bu çağan beklediği şeyler de var.

c. Yani ee bi şekilde estetik anlamda ee daha ee işte biraz önce ... Bey'in $e e$ böyle bi çırpıda söylediği (TK-K-3)

(44) elmacik kemikleri (estetik cerrah (E), NTV_0108)

(45) a. işte elmacık kemikleri.

b. işte falan.

c. Ben şey yapamadım ama ee pat pat pat.

d. Mesela herhangi bir genç kız bunu eminim bunu tak tak tak sayıyordur. (TK-K-3)

(iii) Yarım bırakılmış yapılar: Derlemdeki yarım bırakılmış sözcük $(2 \mathrm{c}, 7,8 \mathrm{~b}$, $18 \mathrm{~g}, 26 \mathrm{i}, 28 \mathrm{~b}, 36,37$ ) ve tümce parçaları (federal yapı olmaması demek de (14b), (24a), ата bunu- (26a)) atlanabilir.

(iv) Onarım yapıları: Derlemde sözcük değişikliği içermeyen, yinelemeye dayalı onarım yapıları (13) ile sözcük değişikliği içeren onarım yapılarına rastlanılmıştır (işi yerine konuyu (2a), el yerine avuç (8b), çıkarına yerine işine (9), fikir yerine ifade (13), hepsine yerine başına (36)). Bu yapılar da atlanabilir. Onarılamamış yanlış ya da anlamsız yapılar da çıkarılmalıdır (10b).

(v) Yinelemeler: Derlemde artıklık gösteren çok sayıda yineleme (gene bu dönemde tırnak içinde, bu dönemde (1), terör örgütünün (2c), bir çıkış (2c), mesele (7), uzun (33)) ve bağlamdan kestirilebilecek, gereksiz açıklama içeren ifadelerle karşılaşılmıştır (6b, 19g, 22a, 22d, 23a, 23c, 38e). (35)'teki gibi önceki ifadeyle (ăgırland $\iota)$ aynı bilgiyi aktaran (Gitti, geldi falan yani.) içerik 
çıkarılabilir. (35)’te bunun başındaki varken insan sözcüğü de gereksizdir. Konuşmacıların birbirlerinin sözlerini kendi sözcükleriyle yineledikleri, onaylayıcı ifadeler $(30,31,40)$ ve konuşmacının kendi kendine sorup yanıtladığı sorular $(18 \mathrm{~b}, \mathrm{f})$ atlanabilir.

(vi) Kişisel görüş gösteren yapılar: Derlemde öznel değerlendirme içeren ( bu da dehşet (26f), ne olursa olsun (1)) yapıların yanısıra, bana göre (TY-E-3, TK-E-5), benim düşüncem (TK-E-5), bence (14g, 23b), kanaatimce (TK-E-2), bizim açımızdan (14a), diye düşünüyorum (9, 27), diyorum (26c), anladı̆̆ım kadarlyla (38d) gibi kişisel görüş gösteren; hatta aynı tümcede birden fazla görüş ifadesi barındıranlar (46) bulunmaktadır. Bu tür yapıların atlanmasında bir sakınca görünmemektedir. Biliyoruz ki, zannediyorlar ki, diyelim (ki) (54), dedi ki (64f) gibi yapılar da çekimli ana tümceyle beraber yer aldığından tümce yapısı bozulmadan çıkarılabilir. (Odaklanmamış) açık adıllar (bunların, bunlara (13), biz (19c), ben (22a), ben, buna (26h), ben şahsım (48), ben hemen (22d)) atlanabilirken konu değiştiren (ben 41c), karşıtlık (ben/herhangi bir genç $k ı z 45 \mathrm{c}-\mathrm{d}$ ) ya da benzerlik gösteren adıllarsa (ben de 49) çıkarılamaz.

(46) Bence bunun önemli olduğunu düşünüyorum. (TY-E-4)

(vii) Kişilerarası ilişkilere yönelik ifadeler: Derlemde konuşmacıların öteki katılımcılarla olumlu bir ilişki kurmalarını sağlayan çeşitli ifadeler bulunmaktadır: ilişkisel işlev taşıyan (biliyorsunuz 18h, 32), incelik gösteren (lütfen 21) ve sayg1/yakınlık gösteren hitap sözleri (teyzem (muhabir (K), HB3), hocam (21), kardeşim (26e), yavrum (kadın, HB3), sayın (22e), hanım (27), sevgili izleyiciler (HALKTV_2707). Konuşmacı değişikliğinin (renk, kişi adı ya da kısa çizgi yoluyla) belirtildiği altyazılarda ya da ilgili konuşmacıların görüntülendiği durumlarda (örn. moderatör sözü bir konuşmacıya bırakırken) hitap sözleri atlanabilirken programda yer almayıp adı geçen kişiler için sayın sözünün kullanılmaması (24b) kabalık olarak kabul edilebilir.

(viii) Bilgi içeriği düşük biçimbirimler: Derlemde etki alanlarında yer alan sözcük, öbek ya da tümceleri çeşitli yönlerden nitelemekle beraber aktarılan ileti açısından elzem olmayan biçimbirimlere rastlanılmıştır. YS'de asıl sorun, hangi biçimbirimin hangi bağlamda çıkarılabileceğine saniyeler içinde karar vermenin güçlüğüdür. Derlemde öne çıkan görevlerine göre kabaca sınıflandırılmış olan bu biçimbirimlerden bazıları örnekleriyle beraber aşağıda sunulmuştur.

Bağlaçlar: Altyazı uygulamalarında, (sözcük çeşitliliği ve bağlaşıklık azalsa da) fazla yer kaplayan bağlaçlar kısa olanlarla değiştirilmekte; hatta çıkarılmaktadır. Derlemde zaman (ardından), ekleme (ayrıca, dA, hatta, hem, mesela, ve), karşıtlik (ama, ancak, bununla birlikte, fakat, öte yandan) ve nedensellik (bu sebeple, çünkü, dolayısılla, o yüzden) gösteren bağlaçlara rastlanılmıştır. $\mathrm{Bu}$ kısa ve yalın bağlaçların çoğunun atlanması uygun 
görünmemektedir. Ancak, yukarıdaki ama (19a), ayrıca (28a), çünkü (38d), de (28c, 38b/d), mesela (24g), ve (24d) bulundukları bağlamda gereksizdir. (47)'de mesela ve/veya diyelim de fazlalıktır.

(47) Mesela diyelim bizi rahatsı eden gida varsa yememek lazım. (gastroenterelog (E), HB5)

Belirteçler/belirtecimsiler: Derlemdeki zaman/görünüş belirteçleri arasında (artık, asla, bir anda, biraz önce, bugün, bugünlerde, çoktan, daha önce, daha sonra, derhal, dün, eskiden, gene, hâlâ, hemen, her zaman, hızla, o anda, son yıllarda, şu anda, tekrar, uzun zamandır, yarın, yavaş yavaş, yine, zaman zaman); kiplik ifadeleri arasındaysa (açıkçası, az kalsın, belki, belli ki, çok şükür, demek ki, doğrusu, eminim, gerçekten, galiba, hakikaten, herhalde, inşallah, keşke, kimbilir, neredeyse, neyse ki, sanki, tesadüfen, zaten) sayılabilir. Bu ifadelerin çoğunun gözlenen sıklığı düşük olduğundan YS'de atlanmalarının altyazıların kısaltılmasına önemli bir katkısı olmayacaktır. Tümcede aynı anlamı veren eylem çekim eki (daha önce ve geçmiş zaman eki DI (24c); herhalde ve kanitsallik eki -DIr (27); eminim ve -DIr (45d)) bulunduğundaysa atlanmalarında bir sakınca yoktur. Artık (25), bu ara (15b), hemen (17a), hemen şimdi (17a), herhalde (36b, 38b), şimdi hemen hızla (20), son (26b), şu anda (24e) belirteçleri bulundukları bağlamda gereksizdir.

Niteleyiciler: Derlemde biçem ya da nitelik gösteren sıfatların yanısıra miktar gösteren niteleyiciler de (biraz, (bir)çok, çok, son derece, tamamen) bulunmaktadır. Genel olarak, sıfattan önce gelen çok ve biraz/biraz daha ile eylemden önce gelen çoklen çok atlanabilir. Miktar niteleyicilerinden bütün (12), ciddi ölçüde (2c), çok (5, 15a, 48), çok da fazla (5), hiç (26h, 51), sonuna dek (23d) ile biçem gösteren doğrudan (12) ve tek tek (22c) bulundukları bağlamda fazlalıktır.

(48) Asitli içecekler ben şahsım, hiç asla kullanmam. Çünkü çok kalorisi yüksek. (gastroenterolog (E), HB5)

Pekiştiriciler: Pekiştiriciler de vurgulama amacıyla kullanıldığından anlam yitimine neden olmadan çıkarılabilir. (49)'da acaba olmadan da soru sorulabilir; (50)'deyse - $(y) s A$ sayesinde peki olmadan da olasiliklar sorgulanabilir. Koşul yapılarında $-(y) s A$ olduğu sürece eğer (17a, 17b) ve şayet gereksizdir; hatta -(y)sA olmadan dilbilgiselliği bozmaktadır (17a).

(49) "Ben de başvursam acaba olur mu" dedim. (K, HB2)

(50) Peki yarın yarın Esat dese ki. (TP-TM-E-2) 
Odaklayıcılar: Bile, hatta, hele, özellikle, sadece gibi biçimbirimlerin atlanabileceği bağlamlar kısıtlıdır. (51)'deki bile çıkarılamazken (52)'de aynı işlevi gören hatta ve bile biçimbirimlerden biri atlanabilir.

(51) Bebeklerde bile reflü oluyor. (gastroenterolog (E), HB5)

(52) Konutta şu anda bi banka hatta faiz indirimi olmadan bile 1 4'e indirmişti. (HK-E-1)

Söylem belirleyicileri: Derlemde (söylemde bilgi akışının düzenlenmesinden başka görevler de üstlenebilen) bak(in), bir kere/defa, efendim, evet, hani, işte, öncelikle, şimdi, tabii, ya, yani gibi biçimbirimlere rastlanılmıştır. Artıklık gösterdikleri için çıkarılabilecek olanlar şöyledir: aslında (22b), bi defa (8a) ve bi kere (18a). Ancak, bu biçimbirimlerin bağlama bakılmadan atlanmaları sakıncalı olabilir.

$B a k($ In), hitap edilen kişinin dikkatini yönlendirmek için kullanıldığında atlanabilirken (24a, 26c, 56d) "bakışı bir noktaya çevirmek" ya da "değerlendirmek" anlamındayken (19b, 19e, 36a) çıkarılamaz.

Efendim, birden fazla anlamı olsa da (örn. tümce başında ilgi çekmek için) kullanıldığ1 hiçbir bağlamda elzem değildir (13, 33). (53)’te başkasının sözlerini aktarıp yargılama amacıyla kullanılan neymiş efendim... -mIş yapısı kısaltılarak kullanılmıştır. Başkasının görüşünü aktarmak için $-m I s ̧$ yeterlidir; efendim konuşmacının aktarılan görüşe katılmadığını sezdirmektedir. Görüşmenin tamamında Lozan Antlaşması'nın önemi birçok kez vurgulandığından konuşmacının konuyla ilgili tutumu zaten açıktır.

(53) E durum böyleyken efenim Lozan'ın eksiği varmış. (HK-E-2)

Evet, çoğunlukla olumlu yanıt/onaylama işlevinde kullanılmaktadır. (38a), (54) ve (55b)'deyse konu değiştirme işlevindedir. (54)'te evet ile okunmakta olan gazetedeki haberlerin bittiği ve bir başka gazeteyle devam edileceği belirtilmiştir. (55b)'deki evet ise hem anlatıma geçmeden önce dikkati toparlamak hem de (uydu üzerinden yayınlanan programa uzaktan bağlandığı için ses iletiminde oluşan) gecikmeyi örtmek için kullanılmıştır.

(54) Evet diyelim ve ... gazetesini geride ee bırakalım sevgili seyirciler. (HALKTV_2707_HS_K)

(55) a. O yanıtı NTV'den ... anlatıcak. (spiker (K), NTV_3007_2)

b. Evet. Yüksek Mahkeme'den 26 Temmuz tarihli karara ilişkin değerlendirmeler geldi. (HM-E)

Derlemde $78 \mathrm{kez}$ geçen yani, çoğu zaman dikkatini toparlamaya çalışan konuşmacıların başvurduğu bir dolgu sözcüğüdür (6a, 8a, 24e, 32, 33, 36a). 
Ama (5)'teki gibi açıklama işlevindeyken atlanamaz. Bir başka dolgu sözcüğüyse işte olup atlanmasında bir sakınca görünmemektedir (8b, 12, 15a, 15b, 36a, 38b). Birden fazla işlevi olan hani de derlemdeki bazı kullanımlarında dinleyicinin konuyu zaten bildiğini vurgulamak ya da ortak bir söylemi anımsatmaktan öte bir anlamı olmayan bir dolgu sözcüğ̈̈ gibidir (56b/c/d). (63c)'de böyle hani denildikten sonra 800 salise sessiz duraksama bulunmaktadır. Spiker, bu sözcüğü söyleyeceklerini toparlamak için zaman kazanmak ve izleyicinin dünya bilgisine başvurmak için kullanılmıştır. (64b)'de de bulunan bu işlev (64a)'daki var ya böyle ile desteklenmiştir. Spiker hem sabah haberlerindeki bilgi içeriğini azar azar tümcelere bölmekte hem de izleyiciyi enerjik ve eğlenceli bir sokak diliyle ekrana bağlamaya çalışmaktadır.

(56) a. Ama son yıllarda çok artan bir zayıflık takıntısı ve baskısı var.

b. Hani artık birçok mağazada sadece 34,36 ve 38 beden kıyafetler vitrinde ve askılarda.

c. Hani 40 bedeni istemek zorunda kaliyorsunuz.

d. Ve hani eminim birçok hemcinsim 40 ve üstü bedenleri sorarken " $y a$ kiloluyum işte, görüyosun bak kilo aldım ve veremedim" hissini kendine yaşatıyodur. (TM-K-2)

Şimdi, hem zaman/görünüş hem de söylem belirleyicisi olarak kullanılabilmektedir. Konu değiştirirken dikkat çekme işlevinde (57b) atlanabilirken "artık" (58) ya da "daha yeni”" (59a) anlamındayken çıkarılması anlam yitimine neden olabilecektir.

(57) a. Güvenli bölge Türkiye'nin aleyhine mi lehine mi?

b. Şimdi ben şunu anlamıyorum şimdi.

c. Daha önce 36. paralelin ee kuzeyini uçuşlara kapatan Kuzey Irak'taki güvenli bölge, ee Çekiç Güç tarafından korundu. (TP-TM-E-2)

(58) a. Böyle, hatta o zamanlar bu jipler falan yeni çıkmıştı Amerikan jipleri.

b. Şimdi be- bazıları bedava veriyorlar alınmıyor. (TK-E-6)

(59) a. Devlet şimdi şimdi yeni yeni bir politika oluşturuyor.

b. Yani biz bu göçmenlere ya da bu sığınmacılara n'apıcaz? (TK-E-3)

Tabii, derlemde olumlu yanıt işlevinde (21) ve dolgu sözcüğü olarak (36a) kullanılmış olup bilgi içeriği düşüktür.

Vay, ya, be gibi sokak diline ait biçimbirimlerin de çıkarılmalarında bir sakınca görünmemektedir (ya (56d), var ya böyle (64a), vay, be (60b/c)). 
(60) a. Son hakkımda heyecan yaptım.

b. "Vay sinyal yakmadım".

c. "Vay be şey yapamadım" diye. (sürücü belgesi sınavına giren kadın, HB2)

Toparlarsak, atlama, anlamsal katkısı olmayıp konuyu vurgulamak ya da zaman kazanmak için eklenmiş olabilecek sözcüklere uygulanabilecek bir stratejidir. Bazı biçimbirimlerinse bulundukları bağlam içinde bir değerlendirme yapılmadan atlanmaları sakıncalı olabilir (örn. bilgilendirici tartışma programlarındaki (örn. teknoloji, tıp) uzmanlık terimleri).

\subsection{Yeniden Biçimlendirme}

Derlemde yeniden biçimlendirme/başka biçimde ifade etme stratejisinin uygulanabileceği çeşitli ögelerle karşılaşılmıştır. Örneğin, çevrik eylem yapıları ve karmaşık tümce yapıları sadeleştirilebilir. (16a)'da gelmiş durumda yerine var, (17a)'da durdurulmasl gerekiyor yerine durdurulmalı denilebilir. (61a)'da -(I)yor varken şu anda gereksizdir; (61b)'de dolmuş durumda yerine doldu; (61c)'de kalmış durumda yerine kaldı denilebilir.

(61) a. Şu anda yine aynı sorunu yaşıyoruz.

b. Yine ee anadolu liselerin tamamına yakını dolmuş durumda.

c. Yine imam hatip liseleri kontenjanları ve meslek lisesi kontenjanları boş kalmış durumda. (HK-K/70)

Dile özgü olanaklar farklılaşsa da kip (soru kipinden bildirme kipine), çatı (edilgen yapıdan etken yapıya) ya da anlatım biçiminde (dolaylı anlatımdan dolaysız anlatıma) dönüşüm gerçekleştirilebilmektedir (örn. (62)'de insanlar atılıp edilgen yapıya geçilebilir (düşün-ül-ür-ken)).

(62) İnsanlar Haya geri döner mi diye düşünürken kaçak prenses çoktan muradına erdi. (Dış ses (E), HB1)

Sözcük düzeyinde yeniden biçimlendirme yapılırken, uzun, yerel veya sıklığı düşük sözcükler, daha kısa veya yaygın eşanlamlılarıyla değiştirilebilir. Dikkatsizlikten kaynaklanan yanlış sözcük seçimleri ve dil sürçmeleri de düzeltilebilir. Ancak bu işlemler konuşmacının yaratıcı dil kullanımından doğan biçemini etkileyecek boyutta olmamalıdır. (63)'teki içerik şöyle de ifade edilebilirdi: Böylesi ancak filmlerde olur. Yaşlı bir adam tren kazasından rayların üzerine yatarak kurtuldu. Böylece hem yeri yanlış olan ancak sorunu çözülmüş hem de -DI ekiyle (çarptı) uyanan yanlış önvarsayım ortadan kaldırılmış olurdu. (Devrik tümce ve dolaylı anlatım içeren) (64) ise 3 
yaşındaki bir çocuk havaalanındaki bagaj bandına bindi. biçiminde söylenebilecek olsa da konuşmacının asıl amacı eğlendirmek olduğuna göre biçemsel bir yitim oluşurdu.

(63) a. Şimdi.

b. Benzerlerine filmlerde ancak rastlard $1 \mathrm{k}$.

c. Böyle hani * tren kazalarından ee trene paralel bi şekilde rayların üzerine yatarak kurtulan adamların hikayesini.

d. Hakkaten oldu.

e. Ee bir yaşlı adama tren çarptı.

f. Adam o anda.

g. Yani bir anlık refleks herhalde $b u$.

h. Bir pozisyon ald.

i. Ve bakın ölümden, ölümün kıyısından nasıl döndü. (Spiker (E), HD2)

(64) a. 3 yaşındaki bir çocuk havaalanında bagaj bantları var ya böyle.

b. Hani gidiyo.

c. Hep aklımızdan geçirmişizdir.

d. O aklımızdan geçirdiğimiz şeyi o çocuk yaptı.

e. Bindi bagaj bandina.

f. Ve dedi ki bu nereye gidiyo acaba.

g. $E e$ ve gidebileceği yere kadar gitti. (Spiker (E), HD1)

\section{Sonuc}

$\mathrm{Bu}$ çalışmada, haber bülteni, ekonomi ve tartışma programlarından oluşan bir Gİ derlem, sözdizim, anlambilim/edimbilim ve söylem düzeylerinde, nitel yöntemle çözümlenmiştir. Konuşma dilini yansıtan özgün içeriğe YS amacıyla kısaltma/yoğunlaştırma uygulandığı takdirde, sözdizim düzeyinde tümce uzunluğu, etki alanı/sözcük dizilişi ve (özellikle sözcük ve biçimbirim seçiminden kaynaklanan) anlatım bozukluklarının, anlambilim/edimbilim düzeyinde kip, kiplik ve sözeylem ifadelerinin, söylem düzeyinde ise bilgi içeriği düşük ögelerin göz önünde bulundurulması gerektiği gözlemlenmiştir.

Kısaltma/yoğunlaştırma stratejileri açısından, Díaz Cintas \& Remael (2007) ve Luyckx ve diğerleri (2010)'dakilere benzer bulgular elde edilmiştir. Atlanabilecek ögeler arasında şunlar sayılabilir: sesli duraksamalar, dolgu sözcükleri, yarım bırakılmış yapılar, yinelemeler, kişisel görüş gösteren yapılar, kişilerarası ilişkilere yönelik ifadeler ile bilgi içeriği düşük ögelerden (örn. niteleyiciler, pekiştiriciler, söylem belirleyicileri) bulundukları bağlamda artıklık gösterenler. Yeniden biçimlendirme stratejisi de anlam yitimine yol açmamak koşuluyla çeşitli sözcük ve yapıların sadeleştirilmesi ya da başkalarıyla değiştirilmesi biçiminde uygulanabilir. Anlatım bozukluklarına uygulanacak stratejiyeyse bağlama dayalı olarak karar verilmelidir. 
Gecikmeyi önlemek bakımındansa atlamaya öncelik tanınabileceği gözlemlenmiştir. Yukarıda sunulan örnekler (1-64) (54 SD ve 20 yarım sözcük çıkarıldıktan sonra) boşluklu 9.118 karakterlik yer kaplamakta olup toplam 1.262 sözcük içermektedir. Yatık yazılan sözcükler çıkarıldığındaysa SS 904'e, boşluklu KS ise 6.911'e düşmektedir. Öyleyse, (dilbilgisel olmaları için yeniden biçimlendirilmesi gereken (8b, 48, 63f, 64a) ve ölçünsüz yazım (örn. söyliyim) gözardı edilerek) sadece atlama yoluyla altyazı içeriği \%24,2 oranında kısaltılabilecektir. Bu açıdan, bir yandan yüksek OKT başarımı için özgün sözcükleri özenle yineleyip bir yandan da noktalama işaretlerini dikte ettiren YS görevlisi için atlama, daha az dikkat/bilişsel çaba gerektiren ve gecikmeyi azaltan bir strateji olabilir. Yeniden biçimlendirmeyse, düşüncelerini toparlayamayan konuşmacıların ürettiği dilbilgisel olmayan yapıların (örn. eksik/uyumsuz ekler) ya da dilbilgisel olsa da anlama güçlüğü yaratan uzun ve/veya devrik tümcelerin düzeltilmesi için yararlıdır. Ancak atlamaya göre daha fazla bellek kapasitesinin yanısıra doğaçlama anlatım becerisi de gerektirdiği kestirilebilir. İleride deneysel çalışmalar yapılarak her iki stratejiyle ilgili bu varsayımların doğruluğu sınanmalıdır.

Toparlarsak, YS'de amaç, bilgi yitimine yol açmayan, anlamsal ve yapısal bütünlüğü olan, kolayca okunup anlaşılabilen dilbilgisel tümceler elde etmektir. Ancak, YS görevlisi hem CA'dan yararlanacak kullanıcılara hem de sözlerini aktardığı konuşmacılara karşı sorumludur. Derlemde Türkçeyi her türlü anlam ayrımını iletebilecek kadar ustalıkla kullananlar bulunduğu gibi çeşitli açılardan (örn. tümce yapısı, sözcük seçimi) ifade güçlüğü çekenler de bulunmaktadır. Bu nedenle, konuşmacının biçemini yansıtan ögelere yönelik işlemlere özen gösterilmelidir. Bu çalışmanın kısıtlı kapsamında konuşmaların gerçekleştiği toplumsal, ekonomik ve siyasal bağlama değinilememiştir. İleride yapılacak çalışmalarda YS işlemini etkileyebilecek dilsel ve dildışı bütün etmenler değerlendirilmelidir.

Güncel YS araştırmalarında, YS süreci, YS görevlisi eğitimi, altyazıların çözümlenip niteliğinin değerlendirilmesi ve kullanıcılar tarafından nasıl alımlandığı gibi noktalara odaklanılmaktadır (Romero-Fresco ve diğerleri, 2019, s. 221). YS görevlisine duyulan gereksinimin artmasıyla mesleki bilgi, beceri ve yetkinliklerin tanınması ve mesleğe yatkınlık gibi konuların daha fazla ilgi uyandırması beklenebilir. Türkiye'deyse YS konusunda bir araştırma boşluğu bulunmakta olup çeviri bölümlerinde de YS'ye yönelik herhangi bir eğitsel etkinlik başlatılmamıştır. İleride yapılacak araştırmalarda YS bütün kuramsal ve uygulamalı yönleriyle ele alınmalıdır. Yapıya özgü kısaltma/yoğunlaştırma stratejilerinin saptanmasıysa okuma güçlüğü yaşayanlar için geliştirilmekte olan (sözcük, sözdizim ya da söylem düzeyinde) otomatik metin sadeleştirme uygulamalarında yararlı olabilecektir. 


\section{Kaynaklar}

Arısoy, E. \& Saraçlar, M. (2018). Türkçe haber programları için konuşma tanımanın tekrar gözden geçirilmesi. IEEE (2018 26th Signal Processing and Communications Applications Conference (SIU)). doi: 10.1109/SIU.2018.8404597.

Arısoy, E., Can, D., Parlak, S., Sak, H. \& Saraçlar, M. (2009). Turkish broadcast news transcription and retrieval. IEEE Transactions on Audio, Speech, and Language Processing, 17(5), 874-883.

Chmiel, A., Lijewska, A., Szarkowska, A. \& Dutka, Ł. (2018). Paraphrasing in respeaking - comparing linguistic competence of interpreters, translators and bilinguals. Perspectives, 26(5), 725-744.

Díaz Cintas, J. \& Remael, A. (2007). Audiovisual translation: Subtitling. Manchester: St. Jerome Publishing.

Ilgın, L. (2003). Televizyon haberlerinde dil kullanımı. G. König, N. Büyükkantarcığlu \& F. Karahan (Ed.) 16. Dilbilim Kurultayı Bildirileri içinde (ss. 97-111). Ankara: Hacettepe Üniv. Yay.

Lambourne, A. (2006). Subtitle respeaking: A new skill for a new age. inTRAlinea, 10, $1-4$.

Luyckx, B., Delbeke, T., Van Waes, L., Leijten, M. \& Remael, A. (2010). Live subtitling with speech recognition: Causes and consequences of text reduction. Across Languages and Cultures, 14, 15-46.

Radyo Televizyon Üst Kurulu. (2019). Sağırların, işitme ve görme engellilerin görselişitsel medya hizmetlerine erişiminin iyileştirilmesi çalıştayı sonuç bildirisi. Ankara: RTÜK.

Romero-Fresco, P. (2016). Accessing communication: The quality of live subtitles in the UK. Language \& Communication, 49, 56-69.

Romero-Fresco, P., Melchor-Couto, S., Dawson, H., Moores, Z. \& Pedregosa, I. (2019). Respeaking certification: Bringing together training, research and practice. Linguistica Antverpiensia 18, 216-236.

Saraçlar, M., Riley, M., Bocchieri, E. \& Goffin, V. (2002). Towards automatic closed captioning: low latency real time broadcast news transcription. Proceedings of the International Conference on Spoken Language Processing (ICSLP), 2002, 17411744.

Yemenici, A. (1998). Haber tartışmalarında kullanılan dil üzerine bir araştırma. Dilbilim Araştırmaları, 1998, 26-36.

Yemenici, A. (1999). Konuşma çözümlemesi: haber tartışmalarında politikacıların kaçamak yanıt stratejileri ile sunucuların karşı stratejileri. Dilbilim Araştırmaları, 1999, 33-44.

\section{Ek: Haber no/ Konu/ Kanal/ Tarih/ Toplam süre (sn.)/Konuşmacı/ Tablo 2'deki kesitin süresi/ Meslek}

HB1 (Kaçak Prenses Haya) ATV_2507 (95); HB2 (64 yaşında ehliyet alan Dudu Teyze) BEYAZTV_3007 (83); HB3 (Düzce'de sel ve hasar tespit çalışmaları) CNNTURK_2607 (180); HB4 (Kaz Dağları'nda protesto eylemi) FOXTV_3107 (166); HB5 (Reflü) KANALD_3007 (115); HB6 (1071 akademisyenin karş1 bildirisi) 
NTV_3007_1 (90); HB7 (Tunceli'de turistik tesis) SHOWTV_2907 (52); HB8 (Eski kocası tarafından öldürülen kadın) STARTV_2507 (90); HB9 (Çiçek açan agave) TGRTHABER_2507_1 (96); HB10 ("Durakta Matematik" projesi) TGRTHABER_2507_2 (121); HB11 (Dondurma dolab1 hirsıları) TGRTHABER_2507_3 (102); HB12 (Boris Johnson'ın göreve başlaması) TRTHABER_2407 (94); HB13 (Kaçak kurbanlık boğa) TRTHABER_2607 (78); (Bagaj bandındaki çocuk) 24_2607_1 (57) HD1/40; (Tren rayındaki adam) 24_2607_2 (61) HD2/38; (Uçan kaykay) 24_2607_3 (120) HD3/86; (CHP'nin soru önergesi) TELE1_2507 (95) HD4/95; (İBB'de Temmuz ödeneğinin nereye harcandığı) TELE1_3007_A (147) HD5/85; HS-K/62; (AYM'nin hak ihlali karar1) HALKTV 2707 (65) (gazete okuma); (AB Merkez Bankası ve faiz oranları) HABERTURK_2707 (83) HE-K-1/83; (Faiz indirimi/S\&P açıklaması) NTV_0708 (76) HE-K-2/76; (Faiz indirim oranları) AHABER_2507 (93) HK-E-1/81 gazeteci-iktisatçı; (Lozan Antlaşması) HALKTV_2407 (90) HK-E-2/90 tarihçi; (Lise kontenjanları) TELE1_3007_B (73) HKK/70 eğitimci; (MSB Bakanı'nın komutanlarla fotoğrafi) NTV_2507 (60) HS-E/60; (AYM'nin hak ihlali kararıly ilgili basın açıklaması) NTV_3007_2 (207) HM-E/193; (Kadın beyni-erkek beyni) CNNTURK_2407 (135) TM-E-1/55; TK-K-1/80 nörolog; (AYM'nin hak ihlali kararı) HABERTURK_0208 (151) TK-E-1/132 milletvekili (hukukçu); (Suriye'de güvenli bölge) HABERTURK_0708 (295) TP-TM-E-2; TP-TKE-7 emekli büyükelçi; TP-TK-E-3 emekli general; (Türkiye'deki Suriyeliler) HABERTURK_3007 (479) TM-K-1/144; TK-E-2/162 akademisyen (hukuk); TK-E3/85 emekli general; TK-E-4/77 gazeteci-yazar; (Ankara Gar Binası'nın tahsisi) HALKTV_0108 (126) TK-K-2/120 mimar; (Siyasetçilerle ilgili söylentiler) HALKTV_3007 (88) TY-E-1/88 emekli siyasetçi; (Kayseri'nin kentsel gelişimi) KENTTURK_2607 (61) TY-E-2/61 gazeteci; (Güzellik bask1s1) NTV_0108 (217) TMK-2/85; TK-K-3/125 psikiyatr; (Suriye'de üniter yapı) NTV_2407 (104) TK-E-5/104 akademisyen (siyaset bilimi); (İklim değişikliği) NTV_3007 (29) TM-K-2/29; (AYM'nin hak ihlali kararı) TELE1_2607 (229) TY-E-3/10 $\overline{6}$ akademisyen (sosyoloji); TY-E-4/123 gazeteci; (Türkiye'de tekstil) TVNET_2707 (63) TK-E-6/63 akademisyen (iktisat) 